\title{
PHILOSOPHICAL STUDIES
}

An International Journal for Philosophy in the Analytic Tradition

Editor: Wilfrid Sellars, University of Pittsburgh

Associate Editor: Keith Lehrer, University of Rochester

Contents of Volume 25, No. 4 - May 1974

Charles Echelbarger / Sellars on Thinking and the Myth of the Given. - Donald Sievert / Hume, Secret Powers, and Induction. - Charles E. Marks / Ginet on Wittgenstein's Argument Against Private Rules. Bredo J. Johnsen / Knowledge. - Sheldon M. Cohen / Sentences, Quotation Marks, and Necessary Truth. - John Tienson / On Analysing Knowledge. - Charles E.M. Dunlop / Performative and Dream Skepticism. - J.O. Wisdom / The Incommensurability Thesis.

Subscription price per volume of six issues Dfl. 90,-, plus Dfl. 12,50 for postage and handling. Nine issues will be published yearly.

Personal subscription price on request.

\section{REIDEL PUBLISHING COMPANY}

Dordrecht - Holland / Boston - U.S.A.

Vol. LXXXIII No. 331

MIND July 1974

Edited by D.W. Hamlyn

Articles

Expressions of Intentions: D. GUSTAFSON

Describing, Evaluating, and Moral Conclusions: C. M. CHERRY

Retained Knowledge: A. HOLLAND

Backwards Causation and Continuing: S. WATERLOW

On Our Knowledge of Matters of Fact: E. SOSA

Criteria for Plausible Arguments: J. AGASSI

\section{Discussions}

Grice and Mackay on Meaning: R. T. GARNER

On "Levels of Rules and Hart's Concept of Law": T. M. BENDITT

Negative Utilitarianism: A. D. M. WALKER

The Explanatory Power of Chomsky's Transformational Generative Grammar: J. SINGLETON

Freedom as the Non-Restriction of Options: W. A. PARENT

Freedom as the Non-Restriction of Options: A Rejoinder: S. I. BENN and W. L, WEINSTEIN

Nullity and Sanction: P. MULLOCK

Tractatus 5.542: M. COHEN

Rights Without Justice: T. D. CAMPBELL

Book Reviews

Books Received

Published for the MIND ASSOCIATION by BASIL BLACKWELL

Single Issues: $80 p$

Annual Subscription: $£ 2.50$ 


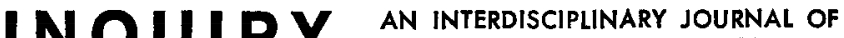 PHILOSOPHY AND THE SOCIAL SCIENCES}

Edited by Arne Naess and Alastair Hannay

\begin{tabular}{|c|c|}
\hline Autumn 1974 & Volume 17 \\
\hline Objectivism and the Study of Man (Part II) & Hans Skjervheim \\
\hline Impossible Objects & Karel Lambert \\
\hline Belief and the Limits of Irrationality & Keith Graham \\
\hline $\begin{array}{l}\text { Discussions: } \\
\text { Von Wright on Historical Causation } \\
\text { Selfishness and Capitalism }\end{array}$ & $\begin{array}{l}\text { Elazar Weinryb } \\
\text { Tibor R. Machan }\end{array}$ \\
\hline $\begin{array}{l}\text { Review Discussions: } \\
\text { Criminal Insanity (H. Fingarette, The Meaning of } \\
\text { Criminal Insanity) } \\
\text { Quinton's Half-Hearted Ontology (A. Quinton, } \\
\text { The Nature of Things) } \\
\text { Cosmic Biology and the "Great Shift" (S. Langer, } \\
\text { Mind: An Essay in Human Feeling, Vol. II) }\end{array}$ & $\begin{array}{l}\text { Herbert Morris } \\
\text { T. L. S. Sprigge } \\
\text { Eva Schaper }\end{array}$ \\
\hline
\end{tabular}

Published quarterly by: Universitetsforlaget

P. O. Box 307, Blindern

Oslo 3, Norway

Annual Subscription: $\quad$ N. kr. $75.00, £ 4.90, \$ 12.50$ (Institutions)

N. kr. $60.00, £ 3.90, \$ 10.00$ (Individuals)

Postage included

\section{THEORIA}

\section{A SWEDISH JOURNAL OF PHILOSOPHY}

Edited by Göran Hermerén and Krister Segerberg

vol. XL, 1, 1974, 60 pp.

\section{CONTENTS}

STEN SPARRE-NILSON

PETER VAN INWAGEN

KIT FINE

R.H. THOMASON
Two additional remarks on the logic of historical explanation

A formal approach to the problem of free will and determinism

An incomplete logic containing $\$ 4$

An incompleteness theorem in modal logic

Reviews by R. Eugene Bales and Thomas E. Hill, jr.

THEORIA, which invites contributions in all fields of analytic philosophy, is published three times a year. Subscriptions and requests for back numbers should be sent to the publishers, Messrs. C.W.K. Gleerup, Box 1205, 22105 Lund 1, Sweden.

Annual subscription is Skr. 35:- (approx. 7 US \$). 


\section{AMERICAN PHILOSOPHICAL QUARTERLY}

\section{Edited by NICHOLAS RESCHER}

Volume 11/Number 4

October 1974

\section{CONTENTS}

I. EDWIN CURLEY: Recent Work on 17th Century Continental Philosophy

II. Peter Achinstein: The Identity of Properties

III. Robert SOLOMON: Hegel's Epistemology

IV. RichaRd Schacht: On "Existentialism", Existenz-Philosophy and Philosophical Anthropology

V. SOUREN TEGHRARIAN: Linguistic Rules and Semantic Interpretation

VI. VIRGIL C. AldRICH: Sight and Light

VII. ROBERT HOFFMAN: Vulgarity

VIII. JoHN BeversLuIs: Socratic Definition

IX. DALE GotTlieb: Foundations of Logical Theory

Annual Subscription:

$\$ 18.00$ to Institutions (excluding Annual Monograph, price $\$ 7.00$ )

$\$ 8.00$ to Individuals (including Annual Monograph)

Published by BASIL BLACKWELL. Orders to: 108 Cowley Road, Oxford OX4 1JF, England

\section{The Journal of Philosophy}

Subscriptions at $\$ 10.00$ /year; $\$ 7.00$ to students

$\$ 12.00$ to libraries and institutions

The trustees and editors of the Journal of Philosophy announce an increase in subscription prices, effective in January of 1974. Individual subscriptions will be $\$ 10.00$ /year; library subscriptions will be $\$ 12.00$ /year; student subscriptions will remain as they are: $\$ 7.00 /$ year. An additional $\$ 1.00 /$ year is charged for postage, to subscribers outside the United States, Canada, and Mexico.

Back issues, singly or in volumes, from the founding of the Journal in 1904, are available from this office.

720 PHILOSOPHY HALL, COLUMBIA UNIVERSITY, NYC 10027 


\section{Dialogue}

\section{Index cumulatif - Cumulative Index}

\section{Volumes I-X}

L'Association canadienne de philosophie vient de publier un Index des dix premiers volumes de DIALOGUE. Cet index, bilingue et de même format que la revue, comprend trois sections:

a) une table des collaborateurs d'articles et de comptes rendus

b) une table des auteurs recensés

c) une table des matières.

The Canadian Philosophical Association has just published an Index of the first ten volumes of DIALOGUE. It comprises

a) an index to authors of articles and reviews

b) an index to authors of books reviewed

c) a subject index.

Une annonce prématurée indiquant que l'Index était déjà disponible au coût de $\$ 3.00$ l'exemplaire a parue dans le numéro de DIALOGUE de décembre 1973. A cause de délais imprévisibles et de la hausse constante des prix l'Index sera vendu au prix de $\$ 5.00$. Toute commande doit être payée d'avance.

An announcement appeared in the December 1973 issue of DIALOGUE stating that the Index was already available at a cost of $\$ 3.00$ per copy. This announcement was premature. Unavoidable delays in publication and rising costs have necessitated a revised price of $\$ 5.00$. All orders must be prepaid.

Adresser vos commandes à / Mail your order to:

Association canadienne de Philosophie

Canadian Philosophical Association

Suite 46, 1390 ouest, Sherbrooke West,

Montréal, Québec, H3G 1K2,

Canada. 


\section{CONGRÈS D'OTTAWA SUR KANT — OTTAWA CONGRESS ON KANT}

The Faculty of Philosophy of the University of Ottawa is sponsoring the Ottawa Congress on "Kant in the Englishspeaking and Continental Traditions" to be held from October 10 to 14,1974 . The purpose of this congress is to provide a meeting ground for an exchange of views between European and American philosophers. Papers will focus on both general and specific problems related to each of the three Critiques.

Registration is $\$ 15.00$ ( $\$ 5.00$ students) made payable to University of Ottawa (Re: Kant Congress).

Further information may be obtained from:

Brian Morrisey, Executive Secretary

Ottawa Congress on Kant

Faculty of Philosophy

University of Ottawa

Ottawa, K1N 6N5, Canada

Conférenciers invités/Invited Speakers:

L.W. Beck, R.E. Butts, D.P. Dryer, J.N. Findlay, Gerhard Funke, Louis Guillermit, Gérard Lebrun, J.D. McFarland, Olivier Reboul, Jonathan Robinson, G.A. Schrader, Wilfred Sellars, J.R. Silber, Jacques Taminiaux, Jules Vuillemin, W.H. Walsh, T.C. Williams, A.W. Wood.

La Faculté de Philosophie de l'Université d'Ottawa organise un congrès sur Kant du point de vue des traditions anglophone et continentale. Ce congrès aura lieu du 10 au 14 octobre 1974 à l'Université d'Ottawa. Il a pour but de permettre des échanges d'opinions entre philosophes d'Europe et d'Amérique sur les thèmes généraux et les problèmes particuliers qui se trouvent impliqués dans les trois Critiques.

Les frais d'inscription sont de $\$ 15.00$ (étudiants, $\$ 5.00$ ). Les chèques doivent être établis à l'ordre de: Université d'Ottawa (Re: Congrès sur Kant).

Pour plus de renseignements, prière de s'adresser à:

Brian Morrisey, Secrétaire exécutif

Congrès d'Ottawa sur Kant

Faculté de philosophie

Université d'Ottawa

Ottawa, K1N 6N5, Canada 


\section{CHRONIQUE - ANNOUNCEMENTS}

A new journal, TEACHING PHILOSOPHY, will appear twice yearly beginning January, 1975. The editors, Arnold Wilson and William Todd, invite papers concerned with any facets of the teaching of philosophy and the planning of philosophy courses and curricula. Reports on innovative efforts, articles on the training of teachers of philosophy, and assessments of the likely impact of new teaching ideas for the discipline, as well as notes and news items, are all welcome.

A regular feature will be critical notices of textbooks and surveys of materials available for teaching particular areas - recent texts in introductory logic, for example. Persons interested in contributing such notices, should write the editors, indicating their areas of interest.

Address all communications to The Editors, TEACHING PHILOSOPHY, Mail Location 47, University of Cincinnati, Cincinnati, Ohio 45221.

\section{A CONFERENCE ON THE GOOD SOCIETY}

\section{The Empress Hotel, Victoria, B. C.}

\section{October 12-13, 1974}

The Department of Philosophy, University of Victoria, announces a multi-disciplinary Conference on the Good Society sponsored by the University of Victoria, Simon Fraser University and the Canada Council. Principal speakers will include:

Hector-Neri Castañeda (Philosophy), Indiana University Milton Kotler (Political Science), Institute for Policy Studies Scott Gordon (Economics), Queen's University Indiana University

C. A. Hooker (Philosophy), University of Western Ontario John Livingston (Environmental Studies), York University

For further information please write to: Mrs. D. Frampton, Secretary, Department of Philosophy, University of Victoria, Victoria, B. C. V8W 2 Y2. 


\section{LA SOCIÉTÉ DE PHILOSOPHIE DU QUÉBEC}

Lors de sa première assemblée générale tenue le 9 mai 1974 à l'Université Laval, la Société de Philosophie du Québec a procédé à l'adoption des statuts qui guideront la marche de ses activités et à la nomination des membres de son Bureau de direction et de son Conseil d'administration.

M. Paul-André Quintin (UQTR) a été élu président; Paul Germain (Univ. Sir George Williams) 1er vice-président; Raymond Brouillet (Univ. Laval) 2e vice-président; Claude Panaccio (CEGEP de Maisonneuve) secrétaire; Yvan Cloutier (CEGEP de Sherbrooke) secrétaire-adjoint; Pierre Gravel (Univ. de Montréal) trésorier.

Outre les membres du Bureau de direction, le Conseil d'administration est composé de représentants des diverses régions du Québec et d'autres lieux de francophonie: pour Chicoutimi, Claude Vallières (CEGEP de Chicoutimi); pour l'Acadie, Mlle Corinne Galant et Maurice Rainville (Univ. de Moncton); pour Montréal, Robert Nadeau (UQAM), Maurice Lagueux (Univ. de Montréal) et Mlle Lise Bouchard (CEGEP Marguerite-Bourgeois); pour Ottawa et l'Outaouais, Pierre Laberge (Univ. d'Ottawa) et Bernard Ouellet (CEGEP de Hull); pour Québec, Guy Bouchard (Univ. Laval) et Maurice Bailly (CEGEP F.-X. Garneau); pour Rimousky, Claudette Lafond (CEGEP de Rimouski); pour Sherbrooke, Louis Valcke et Jacques Plamondon (Univ. de Sherbrooke); pour TroisRivières, Alain Lallier (CEGEP de Trois-Rivières) et Claude Savary (UQTR).

A titre de président sortant, M. Venant Cauchy (Univ. de Montréal), président fondateur de la S.P.Q. fait aussi partie du Conseil d'administration pour une période de deux ans.

Pendant cette première année d'existence, la S.P.Q. s'est donnée comme priorité de susciter et supporter les activités régionales et d'assurer l'information de ses membres sur ces activités. Cette priorité s'inscrit par ailleurs dans les buts généraux de la Société qui sont les suivants:

a) assurer une diffusion aussi complète que possible d'informations concernant la discipline et la profession;

b) faciliter les échanges entre les divers milieux francophones;

c) favoriser les études philosophiques par la discussion, la recherche et les publications;

d) assumer le rôle de porte-parole de la discipline et de la profession auprès des organismes gouvernementaux ou autres.

La société comprend à la fois des membres ordinaires (enseignants ou non-enseignants), des membres associés et des membres institutionnels.

Le siège social et le secrétariat administratif de la Société sont à Montréal, 2910 boulevard Montpetit. 